\title{
Introduction to Workers, Collectivism and the Law
}

Nationalistic parties blazing across too many horizons, declining union density, Europeanization, and globalization have all contributed to a cauldron of change that strains the constellations of industrial relations forged in the nineteenth-century social movements. Further challenges have been posed in Europe by the delicate, if tenuous, balance in European Union law between freedom of movement, EU social objectives, and continued member state autonomy in the area of labor law. The EU Charter and the European Convention after the 2007 Lisbon Treaty have received greater attention, and it is arguable that a new era is beginning with this stronger focus on human rights and access to justice. Parallel to and fueled by these developments of greater emphasis on human rights at all levels-international, regional, and national-are expanded concepts of democracy. Given these forces, the time is ripe for a reappraisal of the institutional frameworks of employee collectivism against the background of these modern trends. The focus of this book is on different elements that can be identified as facilitating employee voice within the collective, particularly concerning employee grievances, as well as rights of procedural due process and access to justice as components of democracy.

To this end, first, developments in concepts of democracy as well as histories of collective labor organization are presented. The Western history of worker organizations has been inextricably intertwined with social unrest, mercantilism, nationalism, the voting franchise, industrialism, wars, and even plague. Four national systems - those of the United Kingdom, Germany, Sweden, and the United States-are laid out. The comparison first focuses on worker organizations in their incipient form-the guilds-and the transition from the medieval corporative structures to the modern labor union movements. The role of the law with respect to workers and the collective is generally traced throughout this history. The presentations of the modern labor law systems focus on how democracy has been inserted in the paradigms created by law, collective agreements, and custom in these industrial relations with respect to union members. Habermas' procedural democracy is a starting point for the 
analysis of the modern labor law models. It provides a framework by which to assess the issue of labor union members' rights/abilities to concretely influence the actions of both employers and labor unions internally and externally as defined by law and/or collective agreements, as well as the legal mechanisms existing regarding labor unions' responsiveness to members.

After the presentation of the general history and legal structures of the national labor law systems, the focus of the comparison narrows down to the specific topic of employee grievances, and the role of employers, employees, unions, works councils, tribunals and courts in facilitating the pursuit of employee grievances. The procedural focus on grievances was chosen to highlight the relationship between these different actors in a way that underscores questions of workplace democracy and access to justice. Many aspects of employee grievance procedures are set out in the legislation and/or in collective agreements. The issue was also chosen as it is indicative of union responsiveness to employee needs. Employees' rights regarding grievances, such as access to dispute resolution systems, are viewed in light of the alternatives provided in order to raise such complaints-either through the unions or, as is the case in Germany, works councils; to the employer directly or through a tribunal—and with regard to the decision makers handling such grievances.

This is a comparative work seeking to highlight how, as an aspect of industrial democracy, employee voice-both collective and individualassumes different guises in the different models of legal and industrial relations. The objective is to identify issues of voice, access, and equality. At a time when certain labor rights are gaining status as human rights, a comparison of different systems, delineating the boundaries of such rights, is warranted by the protections sought and granted. The historical trajectories of these four systems have greatly affected their outcomes, in the form of today's national labor law models, as well as those key issues still contested in the different forums between the social partners, employees, and the state.

The book is divided into three sections, the first of which is this Introduction, which sets out the theoretical framework for the comparative analysis and includes a short history of the conception of democracy. Part I then addresses the historical origins of collective worker organizations in Northern Europe, originally in the form of the guild system; it moves on to take in the United Kingdom, and more specifically England; then Germany; and then Sweden. The transition from the guild systems, later expanded to journeymen's associations, to the modern worker organizations - first trade and labor associations, societies, and clubs, then ultimately trade or labor unions-is examined 
in Chapters 1 through 6. The United States is also included here, as a historical newcomer. Chapter 7 provides a short history of labor initiatives on the international and regional levels concerning labor conditions, originally with a focus on outlawing the slave trade, and then turning to improvement of worker safety. Modern international and regional efforts focus on strengthening employee rights by providing access to justice as well as damage awards that can deter unwanted conduct. This international and regional focus runs parallel to, and has greatly affected the evolution of, the national legal models. The chapters in Part II present the current individual national systems by country. The final chapter compares these different systems from the perspective of procedural democracy.

\section{LABOR LAW AND MODELS}

As an academic legal subject, labor law is a relative newcomer when compared to other topics, for example, such as the law of obligations, which finds its roots in Roman law. Traveling merchants and later tramping journeymen contributed early to the creation of a lay systemarguably already in place by the thirteenth century - in which a high degree and exchange of knowledge existed as to the law of the guilds, journeymen's associations, and later even labor unions. Academic investigations of labor law systems began at a comparatively much later stage, pioneered by German scholar Lujo Brentano and his books on the history and developments of the (English) guilds and origins of trade unions ${ }^{1}$ in the early 1870s. ${ }^{2}$ The English Fabian scholars Beatrice Potter Webb and Sidney Webb also contributed to this early research with their books The History of Trade Unionism (1894) and Industrial Democracy (1897), ${ }^{3}$ with Beatrice Potter Webb coining the term "collective bargaining."

The emergence of labor law as an academic legal field was carried on by three generations of German scholarship, beginning with Philipp

1 See Lujo Brentano, Introduction in Toulmin SMITH, ENGLISH GILDSTHE ORIGINAL ORDINANCES OF MORE THAN ONE HUNDRED EARLY ENGLISH GILDS (Oxford University Press 1870) and Lujo BRENTANO, ON THE History AND DEVELOPMENT OF THE GILDS AND THE ORIGIN OF TRADE-Unions (London 1870).

2 See Lujo Brentano, Die Arbeitergilden der Gegenwart (Duncker \& Humblot 1871).

3 See Sidney Webb \& Beatrice Webb, A History of Trade Unionism (Longman, Green \& Co. 1894) and Industrial DEMOCRACY (1897). 
Lotmar's The Labor Contract at the turn of the twentieth century. ${ }^{4}$ His student Hugo Sinzheimer, seen as the father of German labor law in part for his contribution to the drafting of the labor law section of the Weimar Constitution, ${ }^{5}$ carried Lotmar's work further, focusing on the normative function of the collective labor agreement. ${ }^{6}$ Later, Sinzheimer's student Otto Kahn-Freund criticized the case law of the German Labour Court as fascist. ${ }^{7}$ Both Sinzheimer and Kahn-Freund were forced to flee Germany during World War II. Sinzheimer died in 1945 from poor health caused by his imprisonment in a concentration camp; Kahn-Freund eventually became a professor of comparative law at the University of Oxford. There he had considerable influence in the academic establishment of labor law in the United Kingdom, as well as comparative labor law internationally, and articulated a conceptual framework of collective laissez-faire.

Swedish scholars were also addressing issues of workers and the social question, as seen in Carl Livijn's 1893 dissertation on social security for workers who had suffered industrial accidents, ${ }^{8}$ and Östen Undén's focus in his 1912 doctoral dissertation on collective agreements under Swedish law. ${ }^{9}$ American professor John Commons was lead editor of the tenvolume collection A Documentary History of American Industrial Society, published in $1910,{ }^{10}$ which formed the basis for his four-volume

4 See Philipp Lotmar, Der Arbeitsvertrag naCh Dem Privatrecht DeS DEUTSCHEN REICHES (Duncker \& Humblot 1902).

5 Certain scholars see Sinzheimer as the father of labor law universally; see, for example, Ruth Dukes, Hugo Sinzheimer and the Constitutional Function of Labour Law in THE IDEA OF LABOUR LAW 57 (Guy Davidov \& Brian Langille eds. Oxford 2011).

6 See Hugo SinZHEIMER, Der KORPORATIVE ARBEITSNORMENVERTRAG: EINE PRIVATRECHTLICHE Undersuchung (Duncker \& Humblot 1907).

7 See OtTo Kahn-Freund, Das SOZIAle IDEAL DES ReICHSARbeitsGERICHTS: EINE KRITISCHE UNTERSUCHUNG ZUR RECHTSPRECHUNG DES REICHSARBEITSGERICHTS IN ABHANDLUNGEN ZUM ARBEITSRECHT VOL. 7 (Bensheimer 1931).

8 See CARL LIVIJN, OM MODERNA SOCIALPOLITISKA LAGAR OCH LAGFÖRSLAG ANGÅENDE ARBETSKLASSENS BETRYGGANDE MOT DE EKONOMISKA FÖLJDERNA AF S.K. OLYCKSFALL I ARBETET (Beckman 1893).

9 See ÖsTEN UNDÉN, KOLLEKTIVAVTALET ENLIGT GÄLLANDE SVENSK RÄTT (Berlingska boktryckeriet 1921).

10 See A Documentary History of American Industrial Society, Vols. 1-10 (John Commons, Ulrich Phillips, Eugene Gilmore, Helen Sumner \& John Andrews eds. Cleveland 1910) and John Commons, David J. Saposs, Helen 
History of Labor in the United States. Commons also drafted the first workers' compensation program in the United States, adopted by the state of Wisconsin in 1911. Commons' doctoral student Edwin Witte later became the architect of the federal Social Security Act of 1935. The high degree of international awareness as to developments in labor law can be seen in the fact that an early 1900s judgment by the UK House of Lords that was negative to English labor unions led almost immediately to legislative discussions in Sweden.

The need for a specific field of labor law was deemed self-evident by these scholars given the lack of parity between employers and employees, who were no longer tied by status, as with masters and journeymen, but simply by contract. Social security also plays an important role in this field, strengthening the position of employees and lessening the power of employers in those systems providing strong social protection such as pensions, sickness insurance, occupational hazard insurance, vacation time, and parental leave. Where labor unions provide such social security, union membership is central to securing these benefits, and unions become quasi-state actors. Where the state provides social security tied to employment, the state becomes a necessary partner to employees and employers. Because of the insertion of social security benefits as well as worker protections, labor law in all of these models extends across both private and public law. Regardless of whether the system terms itself common law or civil law, legislation, case law, and common law principles all come into play in the field of labor law. Collective agreements are normative, but are given different degrees of status in the national labor law systems. Employer practices and agency codes also differ in the extent to which they are concretized in the different models.

An additional complication in the field of labor law is the role of collective organizations, on both the employee and employer sides, in determining norms for different sectors. The European countries chosen for study in this book represent several of the main European labor law models. The United Kingdom forms one end of the spectrum, with modern trade unions originally based on a "collective laissez-faire" economic model as coined by Kahn-Freund, having a strong preference that the state remain neutral and only the social partners should determine the

Sumner, E.B. Mittelman, H.E. Hoaglund, John B. Andrews \& Selig Perman, History of Labor in the United States, Vols. 1-4 (New York: Macmillan 1918). 
conditions in the labor market through collective bargaining: "What the State has not given, the State cannot take away." 11 Germany provides a dual-channel Works Council model and Sweden offers an example of the Nordic model based on extensive self-regulation, perhaps the truest example of a one-channel voice system. The United States was chosen for its stark contrast to the European approaches, particularly from the perspectives of judicial and state intervention.

Industrial democracy is also a component in the delegation of social partners' roles. The treatment of industrial democracy is ideologically based on different premises, such as that greater control by individual workers increases their overall quality of life. Those employers supporting industrial democracy also do so for different reasons, most often to improve worker morale and productivity. ${ }^{12}$ Industrial democracy can be categorized as either direct or indirect. Direct forms can be seen at the local level, where the employees most affected by a workplace decision have a voice in that decision. Representative or indirect industrial democracy involves the use of representatives, chosen or elected to represent either employers or employees, negotiating and/or deciding workplace issues. Labor unions often act as such representatives for their employee members, but other, nonunion forms also exist, such as works councils. There are five different levels of modern worker consultation that can be roughly identified: the provision of information; two-way communications; consultation in decision making; joint decision making/ codetermination; and the delegation of certain types of decision making. ${ }^{13}$ The degree of worker autonomy increases incrementally with each of these types, and the national labor law models taken up here are located at different points on the scale. Issues of a "representation gap" can arise, for example, where groups of workers are excluded from these indirect forms of representation, such as unorganized workers where the labor union has strong rights, or temporary workers where permanent employment is required for representatives to be chosen.

These four national systems also run the gamut of legislative perspectives, from the Swedish minimalist approach to the more heavyhanded US and UK ones. Social democracy as a political movement is also a

11 See Otto Kahn-Freund, Labour Law, in LAW AND PUBLIC OPINION IN BRITAIN IN THE TwENTIETH CENTURY 244 (Morris Ginsberg ed., London 1959).

12 See Greg Patmore, Worker Voice-EMployeE RePresentation IN THE WorkPlace in Australia, Canada, Germany, the UK AND the US 191419391 (Liverpool University Press 2016).

13 See Mick Marchington, Joint COnSultation Revisited 7 (Centre for Research in Industrial Democracy and Participation 1985). 
thread in this tapestry, playing a major role in the European transition from the guilds to trade unions and in the modern history of labor, with the United Kingdom, Germany, and Sweden having had social democratic governmental constellations over significant periods of time. The social democratic movement was seen as a third way between capitalism and radicalism and the period between 1945 and the early 1970s has been hailed as its "golden age," during which it "fought to entrench universal social citizenship encapsulated in the welfare state and a model of regulated capitalism that protected national populations from misfortune." 14 Despite this universal goal, social democracy began to take on different forms in the different European countries after its purported golden age, in efforts to reconcile social democratic models to the economic and ideological challenges presented in the post-Cold War period. Three models of social democracy can be identified: traditional, modernized, and liberalized. In traditional social democracy, the parties have largely retained their original objectives and policy instruments, and their heavy emphasis on state economic intervention is unchanged. Germany is an example here. In modernized social democracy, the objectives have remained the same, but new policy approaches have been adopted. Sweden is an example, with policies such as welfare to work (arbetslinje). In a liberalized social democracy, both the objectives and methods have changed, as can be seen in such policies as the replacement of the traditional emphasis on equality and redistribution with social inclusion. The United Kingdom is an example here. ${ }^{15}$

\section{METHODOLOGY AND COMPARATIVE LABOR LAW}

The idea of comparative labor law and industrial relations is neither new nor untouched. The pioneer in this field-again, Kahn-Freund-raised issues as early as the 1970s, when the United Kingdom was about to join what later became the EU, as to the limits of comparisons to-and, more importantly, borrowing from-foreign legal systems outside their context.

14 See Patrick Diamond, From Fatalism to Fraternity: Governing Purpose and the Good Society in AfTER THE THIRD WAY-THE Future OF SocIAL Democracy IN Europe 3 (Olaf Camme \& Patrick Diamond eds. London 2012).

15 See Wolfgang Merkel, Social Democracy in Power: Explaining The Capacity to Reform, 1(1) ZeITSCHRIFT FÜR VERGLEICHENDE POLITIKWISSENSCHAFT 125-45, 134-5 (2007). 
In his famous words:

The use of the comparative method requires a knowledge not only of the foreign law, but also of its social, and above all its political context. The use of comparative law for practical purposes becomes an abuse only if it is informed by a legalistic spirit which ignores this context of the law. ${ }^{16}$

In the current work, in order to allow for a more contextual assessment, the system dynamics approach to comparative law is chosen as the framework of comparison. This approach, ${ }^{17}$ whose object is to capture and represent influences as to the law as such, takes into consideration four principal sources: legal texts; institutions; decision-making communities; and patterns of thought or discourses. The texts here are legislation, case law, and collective agreements as well as the documented custom and usage of administrative agencies and employers. The objective is to "reveal patterns in the ways that texts operate in legal systems-how they influence decisions and are influenced by those decisions."18 The institutions included here are those with decisionmaking functions: guilds; employers; employee and employer organizations; the state; and tribunals. The decision-makers and institutions are placed within their broader communities. Finally, the patterns of thought, or discourses, are compared as deciphered from the interaction of these three components and the historical development of the different labor law models. Given the number of systems examined, the ambition here is not to provide exhaustive accounts or comparisons of the national systems but rather to set out their main features-the bones, so to speak.

Aspects of a procedural democracy model will be assessed against this comparison of legal models, particularly regarding the alternatives employees have with regard to bringing grievances and issues of access to justices. In order to facilitate this assessment, an overview of democratic conceptual models is now provided.

16 See Otto Kahn-Freund, On Uses and Misuses of Comparative Law, 37 MoD. L. REV. 1, 27 (1974).

17 See David J. Gerber, System Dynamics: Toward a Language of Comparative Law?, 46 Ам. J. Comp. L. 719, 722 (1998) and note 5 citing Eric Stein, Uses, Misuses-And Nonuses of Comparative Law, 72 Nw. U. L. REv. 198 (1977) and Alan Watson, Legal Transplants and Law Reform, 92 L. QUART. REV. 79 (1976).

18 See Gerber, supra intro. note 13 at 730. 


\section{CONCEPTUAL FRAMEWORKS FOR DEMOCRACY}

\section{Winston Churchill once said:}

Many forms of Government have been tried, and will be tried in this world of sin and woe. No one pretends that democracy is perfect or all-wise. Indeed, it has been said that democracy is the worst form of Government except for all those other forms that have been tried from time to time. ${ }^{19}$

This statement reveals much of the historical development, and skepticism, concerning democracy since its Western inception in Athens around 500 $\mathrm{BC}$. This brief historical account begins there and continues up to modern times, exploring five conceptual models of democracy: direct democracy; indirect democracy, in the form of either liberal or republican democracy; deliberative democracy; and procedural democracy. The historical development of these different models can be seen as being mirrored in the evolution of workers' collectivism, beginning with the early guilds and their initial governance structures of direct democracy. Two aspects of Habermas' procedural democracy are taken up in the comparison of the different modern models of labor law at the conclusion of this work. Despite the complexity of the procedural model of democracy, these two aspects - the system's responsiveness to the needs of its constituency, as well as the interests actually represented-easily lend themselves to this analysis. These two aspects are key to the analysis of the different labor law systems examined below, and to the determination of democratic processes. These are used as support for the argument that a broader understanding of democracy needs to be incorporated in the structure of labor unions and the law in order to more successfully respond to employee interests and better anchor both in today's changing society.

\section{THE ORIGINS OF WESTERN DEMOCRACY: ATHENIAN DIRECT DEMOCRACY}

Dèmokratia, the term invoked by Athenians to describe their governance system, comprises kratos (rule by) and dēmos (the people). ${ }^{20}$ Its roots are

19 See Richard M. Langworth \& Winston Churchill, Churchill by Himself: The Life, Times AND Opinions of Winston CHURCHILl IN His OWN WORDS 57 (Ebury Press 2008), referring to a House of Commons speech given on Nov. 11, 1947.

20 See M.H. Hansen, Democracy/Athenian in Oxford Classical Dictionary (2015) available online at classics.oxfordre.com. 
found in Solon's law reforms during the sixth century BC, particularly with regard to increasing access by the poor to the law courts.21 Cleisthenēs is seen as the architect of democracy through his reorganization of the citizen body a century later, extending political power beyond simply the wealthy to the entire demos of Athens. This extension, however, was still limited to only Athenian citizens, a minority group of males constituting about 30 percent of the free population..$^{22}$

Insights into the internal perception of Athenian democracy can be gleaned from Thucydides' account of a speech made by Pericles, who began: "I shall speak first of our ancestors ... they by their valor transmitted to us a free state." 23

It is true that our government is called a democracy, because its administration is in the hands, not of the few, but of the many ... For we [Athenians] alone regard the man who takes no part in public affairs, not as one who minds his own business, but as good for nothing; and we Athenians decide public questions for ourselves or at least endeavour to arrive at a sound understanding of them, in the belief that it is not debate which is a hindrance to action, but rather not to be instructed by debate before the time comes for action. ${ }^{24}$

This idea of civic duty came to be seen as a cornerstone of the later French republic model of democracy. Athenian democracy lasted almost two centuries, until Macedonia conquered Athens in $338 \mathrm{BC}$.

That democracy was contested as a system as early as the time of the Greeks is evidenced by the writings of Thucydides, Socrates, Plato, and Aristotle. Plato's Socrates argued in The Republic that "such is democracy - a pleasing, lawless, various sort of government, distributing equality to equals and unequals alike."25 Plato's critique of democracy was that the rule of the demos was the rule of the foolish, vicious, and always potentially brutal, and that any stability in such a rule was a sheer fluke. ${ }^{26}$ The ideas articulated above-civic duty, democracy requiring instruction and debate, as well as democracy vulnerable to being reduced

\footnotetext{
21 See John Dunn, Democracy-A History 34 (Penguin 2005).

22 Id. at 35.

23 See Thucydides, Thucydides In Four Volumes: Vol. 1, THE History of the Peloponnesian WaR Books I AND II 320-21 (Charles Forster Smith trans. Harvard University Press 1956). Thucydides lived from approximately 472 to 396 BC.

24 Id. at 322-9.

25 See Plato, The Republic 94 (Benjamin Jowett trans. Project Gutenberg

$26 I d$. at 22.
} 2008). 
to mob rule-still resonate today as central issues when grappling with concepts of democracy.

Almost two millennia then passed during most of which democracy was seen as neither positive nor reliable, but rather was marginalized and viewed with suspicion. Thomas Hobbes considered democracy an unstable form of government that would either revert to anarchy or become a de facto "aristocracy of orators, interrupted sometimes with the temporary monarchy of one."'27

\section{THE LIBERAL MODEL OF DEMOCRACY}

Democracy did not surface again in a positive light until the ratification of the US federal constitution in the 1780s, in which a model of representative democracy was adopted. There were several reasons for this choice, but central to the discussion here was that representative democracy was seen to best balance fears of mob rule by placing the ultimate responsibility for decisions in the hands of elected, informed representatives. Another safeguard was the rule of law, the lawmaker being bound by the constitution, as the United States was (and still is), to be a "government of laws, not of men." ${ }^{28}$ Certain fundamental rights and liberties of minority groups would then be guaranteed as against a rule by the majority, a caveat here being that women and slaves at this time had no participatory rights. An additional safeguard against the temporary monarchy of one orator was the separation of powers, as well as the system of checks and balances between the three different branches of government: the President, Congress, and the Court.

The American model places a great emphasis on voted leaders as opposed to civic duties, developing into what is now considered the liberal model of democracy. The classical liberal view, postulated for example by John Locke, was "wherever law ends, tyranny begins." 29 Locke emphasizes the impersonal rule of law and the protection of

27 See Alan Apperley, Hobbes on Democracy, 19(3) Politics 65-171 (1999), citing Thomas Hobbes, De Cive Philosophical Rudiments Concerning Governing AND Society (1651) in The English Works of ThOMAs HobBes, Vol. IV 141 (William Molesworth ed. London 1840). Hobbes had translated Thucydides into English: THUCYDIDES, EIght BOOKES OF THE PELOPONNESIAN WARRE WritTEN BY THUCYDIDES THE SONNE OF Olorus DATE: 1648 (Thomas Hobbes trans. 1648).

28 See John Adams, 7th “Novanglus" letter, Boston GAZETTE, 1774.

29 See John Locke, Two Treatises OF GOVERnMENT Chapter XVIII Section 202 (Thomas Hollis ed. 1689). 
individual freedom; democratic process is constrained by, and in the service of, personal rights that guarantee individuals the freedom to pursue their own goals and happiness. Legitimate government is defined in relation to the protection of individual liberty and human rights, and questions of private autonomy. The focus is instead on the individual's ability to govern herself, a departure from the medieval corporate conception of democracy - the right of a people to organize into a body free of external interference. The individual under this modern model is capable of self-restraint and no longer needs elaborate institutions to control human vice. ${ }^{30}$

\section{THE REPUBLIC MODEL OF DEMOCRACY}

Representative democracy as a model was quickly established thereafter in Holland and France; in turn, its reach was fairly quickly felt throughout much of Europe. In contrast to the liberal, elective-representative model developed in the United States, the French revolution led to a representative democracy with a greater focus on civic participation. This model of a republic emphasized the democratic process as a collective deliberation that ideally leads citizens to reach agreement on the common good. Human freedom is to be found not in the liberal pursuit of private preferences (happiness) but rather in self-governance through political participation: "liberty, equality and fraternity." Legitimate government is defined in terms of popular sovereignty and public autonomy.

Criticism - in particular of liberal democracy as a tool for capitalismwas raised by Karl Marx prior to World War I. ${ }^{31}$ World War II brought further denunciation, as exemplified by Joseph Schumpeter's argument that the "reduced sense of responsibility and absence of effective volition" found in representative democracies results in the typical citizen dropping "down to a lower level of mental performance as soon as he enters the political field ... He becomes primitive again." ${ }^{32}$ Schumpeter posited that the principle of democracy "merely means that the reins of government should be handed to those who command more support than

30 See Joyce Appleby, The Radical Double-Entendre in the Right to SelfGovernment, in THE ORIGINS OF ANGLO-AMERICAN RADICALISM 275 (Margaret Jacob \& James Jacob eds. London 1984).

31 See Joseph V. Femia, Marxism and Democracy 18 (Oxford University Press 1993).

32 See Joseph A. Schumpeter, Capitalism, Socialism AND Democracy 261 (Martino Publishing, reprint 2011) (2nd ed. 1947). 
do any of the competing individuals or teams," 33 in a modern echo of Hobbes' fear of rule by orators.

\section{DELIBERATIVE DEMOCRACY}

Deliberative democracy-also referred to as discursive democracyattempts to bridge, in part, Schumpeter's criticism of democracy as becoming mindless - that voters who have achieved political equality no longer deliberate when making voting choices. This imbalance is to be redressed through political equality and authentic deliberation. James Fishkin and Robert Luskin define political equality as comprising the equal consideration of everyone's preferences. Here, "everyone" refers to a relevant population or demos. "Equal consideration" entails three things: a process of counting so that everyone has the same voting power, that is, an equal chance to cast a decisive vote; anonymous voting; and the absence of voting track records or preferences.

Deliberation, for Fishkin and Luskin, is a weighing of competing considerations through discussion. Such a weighing is to be characterized by being informed, balanced, conscientious, substantive, and comprehensive. ${ }^{34}$ The weighing is informed, and consequently informative, when the arguments presented are supported by appropriate and reasonably accurate factual claims. "Balanced" entails that counterarguments be presented in order to be able to more thoroughly assess claims. "Conscientious" requires that participants be willing to talk and listen with civility and respect. "Substantive" means that the arguments are to be considered sincerely on their merits, not by how they are made or who is making them. Finally, "comprehensive" means all points of view held by significant portions of the population are to be given attention.

In a somewhat ironic turn, the best known historical example of deliberative democracy in action is the drafting and ratification process of the US federal constitution in the late 1780s. It is ironic because this

\footnotetext{
33 Id. at 73.

34 See James S. Fishkin \& Robert C. Luskin, Experimenting with a Democratic Ideal: Deliberative Polling and Public Opinion, 40 ACTA POLITICA 284, 285 (2005). See also generally, James S. Fishkin, When the People SpeaKDeliberative Democracy and Public Consultation (Oxford University Press 2009). Several others have delineated notions of deliberative democracy, including Joshua Cohen, Amy Gutmann, and Dennis F. Thompson. As the ambition here is to give a short history, the more nuanced aspects of each of these models have been omitted.
} 
deliberative democratic process approved the instrument which ultimately created the imbalance that the deliberative model of democracy is attempting to redress. The drafting of the constitution began in a convention representing 12 states, ${ }^{35}$ then went to committee for report; this report was then discussed by the convention again, compromise was reached, and a draft constitution was decided upon. Benjamin Franklin, when signing the draft, stated, in a manner much in line with the Churchill quote earlier in the chapter: "I consent, Sir, to this Constitution because I expect no better, and because I am not sure, that it is not the best." 36 The draft was then sent to the individual states for debate and ratification by general election. The debates held in the different states concerned the draft as well as issues raised by The Federalist Papers, a collection of 85 essays authored by Alexander Hamilton, James Madison, and John Jay in 1787-88. ${ }^{37}$ This process is seen as one of the best examples of deliberative deliberation because of the level of detail the discussions engendered, the extent of the debates across the 13 states, and the number of individuals freely participating in the debate process.

\section{PROCEDURAL DEMOCRACY}

Jürgen Habermas puts forth a procedural concept of democracy that combines a procedural account of democratic legitimacy with deliberative politics. ${ }^{38}$ Habermas attempts to resolve several issues with this concept, such as the tension between the liberal human rights model and the republic popular sovereignty model, as well as the imbalance between financial resources and power, on one side; and popular sovereignty, on the other. According to this procedural principle of democracy, "[o]nly those statutes may claim legitimacy that can meet with the assent of all citizens

35 The State of Rhode Island and Providence Plantations did not attend for fear of a strong central power, and was the last state to ratify the constitution in 1790.

36 See James Madison, Notes on the Debates in the Federal ConvenTION, TUESDAY SEPTEMBER 17, 1787, available at the website of The Avalon Project, Documents in Law, History and Diplomacy, Yale Law School: avalon. law.yale.edu.

37 See Alexander Hamilton, James Madison, \& John Jay, The FederalIST PAPERS (1787); see the e-text archives of Project Gutenberg, gutenberg.org.

38 See Jeffrey Flynn, Communicative Power in Habermas's Theory of Democracy, 3(4) European Journal of Political TheOry 433 (2004). 
in a discursive process of legislation that in turn has been legally constituted."39 Law is to act as a transformer of communicative power. The exercise of state authority through administrative power is only legitimate if bound to this discursively generated communicative power. Two components can consequently be identified: communicative power; and a responsiveness by the political/administrative system to this communicative power.

The communicative power is of the citizenry. According to Habermas, the principle of democracy mandates that "[j] ust those norms are valid to which all possibly affected persons could agree as participants in rational discourses." 40 The communicative power of the citizenry is to be bound by a set of abstract rights that citizens recognize in order to regulate their lives together by means of legitimate, positive law. Habermas identifies five broad categories of such rights. ${ }^{41}$ The first category comprises the basic rights that result from the politically autonomous elaboration of the right to the greatest possible measure of equal individual liberties. This category of a general right to equal liberties necessitates the following two corollaries:

- Basic rights resulting from the politically autonomous elaboration of the status of a member in a voluntary association of consociates under law; and

- Basic rights resulting immediately from the actionability of rights and from the politically autonomous elaboration of individual legal protection [due process guarantees].

These categories of rights regulate relationships among citizens. Citizens can each claim rights and bring them to bear as against one another. The general right to equal liberties, along with the correlative membership rights and guaranteed legal remedies, establish the legal code as such: in other words, "there is no legitimate law without these rights." 42

The fourth category addresses rights to political participation. This is the basic right to equal opportunities, to participate in processes of opinion and will formation, in which citizens exercise their political autonomy and through which they generate legitimate law. The fifth category concerns the right to social welfare rights. If citizens cannot

\footnotetext{
39 See Jürgen Habermas, Between Facts And Norms 110 (Polity Press 1997).

$40 \quad I d$. at 107 and 111.

41 Id. at 122-23.

42 Id. at 125.
} 
meet their basic material needs, neither private nor public autonomy will be effectively exercised. Basic rights relate to the provision of living conditions that are socially, technologically, and ecologically safeguarded, insofar as the current circumstances make this necessary if citizens are to have equal opportunities to utilize the civil rights listed in the first four categories above. Through this communicative power of the citizenry bound by the above categories of rights, Habermas resolves the tension between popular sovereignty and human rights.

Habermas links the communicative power of the citizenry with the lawmaker's result: "law represents ... the medium for transforming communicative power into administrative power."43 The procedural aspect of this model comes into place here. Only the state can act. State action, however, is legitimate only if the formal decision-making procedures within the constitutional state have a discursive character that preserves, under conditions of complexity, the democratic sources of legitimacy in the public at large. For there to be democratic lawmaking, formally institutionalized deliberation and decision must be open to input from informal public spheres. The political/administrative system cannot become an independent system, operating solely according to its own criteria of efficiency and unresponsive to citizens' concerns. Neither is it to be too subservient to particular interests that have access to administrative power through unofficial paths of influence that bypass the democratic process.

This requirement of responsiveness on the part of the political/ administrative systems to the communicative power of the citizenry also provides a resolution to the tension between formal justice (a liberal paradigm) and substantive justice (a social welfare paradigm). According to the procedural democracy approach, any conflict between these two paradigms has the potential to be resolved by requiring, for the legitimate regulation of the issue, participation in the public discussions of the parties affected. The example given by Habermas concerns women's struggles for equality. Equal voting rights and access to education are based on formal equality and the liberal paradigm. Special aid to women with children to allow women to become better educated, as well as subsidized childcare, fall within the category of a social welfare paradigm (to achieve substantive justice eventually). This latter paradigm is in direct conflict with the first one of formal equality. Under a procedural democracy approach, in order for the regulation of these issues to be

\footnotetext{
43 Id. at 169.
} 
legitimate, women themselves have to participate in the public discussions determining which gender differences are relevant to issues of equality. ${ }^{44}$

The systems' responsiveness is explored in this work through the historical and legal parameters of workers and collectivism, beginning with the guild systems and ending with the modern national labor law models. Historically the guilds might seem far removed, but, as seen in the following chapters, the guild systems, and particularly the journeymen's associations, set out the basic structures for workers' rights: the early labor unions, and the twentieth-century systems of social welfare. The early guilds also demonstrate a model of direct democracy. When that democratic balance within the guilds was disrupted, the model no longer functioned, with journeymen engaging in industrial action against their masters. Today's labor law models are based on representative democracy, and the issue is whether they have made or should make the transition to a procedural democratic model.

Habermas discusses state action, and the question can be, and has been, raised whether labor unions are state actors. Each of the labor law models explored here involve degrees of self-regulation, in that the social partners determine the terms and conditions of employment through collective agreements, some of which, through ergo omnes, are declared nationally applicable in certain sectors. Given this degree of normative rulemaking by the social partners, the same components of procedural democracy should be addressed within labor law models in order to claim legitimacy. After tracing the historical and legal developments of worker collectivism, this work will conclude with a comparative analysis of the different current national labor law models from a procedural democracy perspective.

Part I examines workers, collectivism, and the law historically. "Trade unions are the successors of the old gilds" 45 was the conclusion reached by one of the very first scholars of labor law, the German Lujo Brentano, when tracing the history of the English trade unions. Though describing the English system, this statement is equally applicable to the German and Swedish labor law systems. However, each of these systems had a vital mid-stage, with journeymen's associations playing a central role in fighting for rights, first against the masters and then against employers.

44 Id. at 421-27.

45 See Brentano, supra intro. note 1 at clxv. See also CARola M. Frege, EMPloyment Research AND StATE TRAditions: A COMPARATIVE History OF Britain, Germany and the United States 17 (Oxford 2007). 
The historical and legal development of the guilds, journeymen's associations, and labor unions is set out in this part. The transition from guilds to trade unionism in each of the four countries compared here-the United Kingdom, Germany, Sweden, and the United States-is then briefly traced, followed by a chapter looking at the internationalization of these collective worker efforts.

The history of trade unionism begins in England. There it dovetails into the decline of the guilds, the Reformation's social acceptance of profits, and the rise of journeymen's associations. England was the first country to have trade unions, a result in part of the early forging of a nation state, the early transitions from agricultural to mercantile and then industrial economies, and the parallel early commodification of labor and the tensions that arose between masters and journeymen. The rise of trade unionism in Germany and Sweden followed almost a century later, and almost immediately on the heels of the legislative abolishment of their guild systems. The guild system never quite permeated the American colonies or nation, with the history of the labor movement in the United States having as a starting point the concerns of colonialists focusing on survival in the face of labor shortages.

The modern labor law models of those four countries are set out in Part II. The general organizational structures of the social partners in each of the current national systems addressed here are blends of old unionism, with certain unions still organized in line with the trades or crafts, and new unionism, with union organization based on employer or industry. Each of these national labor organizational systems are also similar in their "bones," starting at the grassroots level with local clubs or unions, then with national unions comprising the locals, then with trade union federations or confederations comprising the nationals. Regional and international organizations, comprising national federations or confederations, add further layers to this structure. An example of the convergence of the organizational structures can be seen in the International Trade Union Confederation, with members from all four countries: the British Trades Union Congress; the German Deutscher Gewerkschaftsbund; the Swedish Landsorganisationen i Sverige, Sveriges Akademikers Centralorganisation, and Tjänstemännens Centralorganisation; and the American Federation of Labor and Congress of Industrial Organizations.

Organizational density is also a vital component in understanding these different labor law models. Historical peaks with respect to union density were reached for the United Kingdom in 1980 with 50 percent, Sweden in 1993 with 84 percent, Germany in 1991 with 36 percent, and the 
United States in 1954 with 35 percent. ${ }^{46}$ Union density in 2014, according to the OECD, was 25.1 percent for the United Kingdom (6.9 million members), 67.3 percent for Sweden (3.5 million members), and 10.7 percent for the United States (15 million members); 18.1 percent for Germany (7.4 million members). The general average for OECD countries in 2014 was 16.7 percent. ${ }^{47}$ Employer organization is not as pervasive in most of these national systems; Sweden is the outlier, with an employer organizational density of more than 87 percent in 2014, surpassing that of labor union density. ${ }^{48}$ Despite differences in numbers, the structures for employer organization in the different national systems are also quite similar in the different national systems, and often mirror the structures on the employee side.

The focus of each chapter in Part II is on the current basic labor law frameworks of the national systems, the legal status of employee organizations, recognition and collective bargaining, the legal status of collective agreements, employee consultation, industrial action, and the peace obligation. Relationships between the unions and employers, then between unions and members are then explored. Workers' ability to affect decisions at the local levels varies in the different national systems, which are all mostly systems of indirect democracy with organizations as members, and not individuals. Individual employee voice is then explored in situations of indirect industrial democracy, namely whether individual workers have sufficient means to hold unions accountable with regard to representing the employee's interests, particularly in grievance procedures. If such means are not available, the question then becomes whether other viable alternatives exist by which individual employees can seek

46 See Martin Upchurch, Graham Taylor, \& Andrew Mathers, The Crisis of Social Democratic Trade Unionism in Western Europe: The SEARCH FOR AlternAtives (Ashgate 2009) and Jelle Visser, Union Membership Statistics in 24 Countries, 38 MONTHLY LABOUR REVIEW 39-49, 45 (January 2006).

47 These OECD statistics as to trade union density are available at the website of the OECD, at stats.oecd.org.

48 See Ewa Persson, Högsta organisationsgraden på sju år för tjänstemannen, ARBETSVÄRLDEN, 18 February 2015, available at arbetsvärlden.se. The degree of organization in Sweden in 2010 was 80 percent by private employers and 100 percent among public employers: see Anders Kjellberg, Kollektivavtalens täckningsgrad samt organisationsgraden hos arbetsgivarförbund och fackförbund, 2013(1) STUdies IN SOCIAL POLICY, IndUSTRIAL RELATIONS, Working Life AND MOBILITY, RESEARCH REPORTS (Lund University 2013). 
remedies within the national labor law models. An examination of worker voice-collectively or individually as to employers, and individually as to employee organizations, as well as access to justice in pursuing employee grievances_concludes each chapter. 